\title{
Organic ligand-induced dissolution kinetics of antimony trioxide
}

\author{
Xingyun $\mathrm{Hu}^{1,2}$, Mengchang $\mathrm{He}^{1, *}$ \\ 1. State Key Laboratory of Water Environment Simulation, School of Environment, Beijing Normal University, Beijing 100875, China. \\ E-mail: xyhu@rcees.ac.cn \\ 2. State Key Laboratory of Environmental Aquatic Chemistry, Research Center for Eco-Environmental Sciences, University of Chinese Academy of \\ Sciences, Beijing 100085, China
}

\section{A R T I C L E I N F O}

Article history:

Received 18 June 2016

Revised 19 August 2016

Accepted 23 September 2016

Available online 15 October 2016

\section{Keywords:}

Antimony pollution

Antimony trioxide

Dissolution

Organic ligands

\begin{abstract}
A B S T R A C T
The influence of low-molecular-weight dissolved organic matter (LMWDOM) on the dissolution rate of $\mathrm{Sb}_{2} \mathrm{O}_{3}$ was investigated. Some representative LMWDOMs with carboxyl, hydroxyl, hydrosulfuryl and amidogen groups occurring naturally in the solution were chosen, namely oxalic acid, citric acid, tartaric acid, EDTA, salicylic acid, phthalandione, glycine, thiolactic acid, xylitol, glucose and catechol. These LMWDOMs were dissolved in inert buffers at $\mathrm{pH}=3.7,6.6$ and 8.6 and added to powdered $\mathrm{Sb}_{2} \mathrm{O}_{3}$ in a stirred, thermostatted reactor $\left(25^{\circ} \mathrm{C}\right)$. The addition of EDTA, tartaric acid, thiolactic acid, citric acid and oxalic acid solutions at $\mathrm{pH} 3.7$ and catechol at $\mathrm{pH} 8.6$ increased the rate of release of antimony. In the $10 \mathrm{mmol} / \mathrm{L}$ thiolactic acid solution, up to $97 \%$ by mass of the antimony was released after 120 min reaction. There was no effect on the dissolution of $\mathrm{Sb}_{2} \mathrm{O}_{3}$ for the other ligands. A weak correlation between dissolution rate with the dissociation constant of ligands and the stability of the dissolved complex was also found. All the results showed that the extent of the promoting effect of ligands on the dissolution of $\mathrm{Sb}_{2} \mathrm{O}_{3}$ was not determined by the stability of the dissolved complex, but by the dissociation constant of ligands and detachment rate of surface chelates from the mineral surface. This study can not only help in further understanding the effect of individual low-molecular-weight organic ligands, but also provides a reference to deduce the effect of natural organic matters with oxygen-bearing functional groups on the dissolution of antimony oxide minerals.

(c) 2016 The Research Center for Eco-Environmental Sciences, Chinese Academy of Sciences.
\end{abstract}

Published by Elsevier B.V.

\section{Introduction}

Antimony $(\mathrm{Sb})$ is a potentially toxic trace element, which is classified as a priority pollutant by the USEPA and the EU (CEC, 1976; USEPA, 1979). In light of antimony's character as an emerging, global pollutant (Amarasiriwardena and Wu, 2011; He et al., 2012; Maher, 2009; Reimann et al., 2010; Shotyk et al., 2005), it is necessary to understand the factors governing its rate of migration rate from its natural sources as well as from polluted environmental compartments. The ore mineral stibnite
$\left(\mathrm{Sb}_{2} \mathrm{~S}_{3}\right)$, associated with its principal weathering products senarmontite (cubic $\mathrm{Sb}_{2} \mathrm{O}_{3}$ ), valentinite (orthorhombic $\mathrm{Sb}_{2} \mathrm{O}_{3}$ ) and stibiconite $\left(\mathrm{Sb}_{3} \mathrm{O}_{6} \mathrm{OH}\right)$, is the most important natural source of antimony in the supergene environment (Filella et al., 2009). It is believed that the dissolution of these phases dramatically contributes to the $\mathrm{Sb}$ pollution in water draining zones. The dissolution behaviors of stibnite and the release kinetics of $\mathrm{Sb}$ from the dissolution of $\mathrm{Sb}_{2} \mathrm{O}_{3}$ under environmental conditions have been investigated widely (Biver and Shotyk, 2012a, 2012b, 2013; Hu et al., 2014, 2015, 2016a, 2016b). Although antimony

\footnotetext{
* Corresponding author. E-mail: hemc@bnu.edu.cn (Mengchang He).
} 
oxide is the primary natural source of antimony, only thermodynamic solubility data (Zotov et al., 2003) and dissolution kinetics at different $\mathrm{pH}$ values are available, while nothing is known on its dissolution kinetics in the presence of ligands. Yet the presence of ligands is thought to contribute significantly to the dissolution of oxide, sulfide and silicate minerals (Aiken et al., 2011; Biber et al., 1994; Brantley, 2008; Davis et al., 1995; Furrer and Stumm, 1986; Gulley-Stahl et al., 2010; Liang et al., 2000; Sposito, 2004; Waples et al., 2005). Because mine areas might comprise deciduous forests, meadows, and farmland, with soil of the dystric cambisol type, when water coming from precipitation and percolating through the soil and the fault system comes into contact with the ores, it can thus be expected to contain organic matter of pedogenic origin. Among the organic carbons in the soil solution, low-molecular-weight organic acids (LMWOA), such as carboxylic acids (e.g., acetic acids, oxalic, tartaric acids, citric acid and aromatic acids), amino acids (e.g., glycine, arginine and lysine) and carbohydrates, along with their polymerized forms, can take up to more than one half of the organic carbons (Sposito, 2008). Biver and Shotyk (2012b) have examined the effect of acetic, oxalic, citric, and salicylic acids, EDTA, glucose, catechol, glycine, cysteine, desferrioxamine-B, and natural chestnut leaf litter extract on the dissolution of stibnite. Both enhancement and retardation of the dissolution rate of $\mathrm{Sb}_{2} \mathrm{~S}_{3}$ were observed, and a linear relationship was found between the rates of ligand-promoted dissolution and the $\mathrm{pK}_{\mathrm{a}}$ values of the ligands. In addition, the stability and structure of aqueous complexes formed by $\mathrm{Sb}$ (III) and $\mathrm{Sb}(\mathrm{V})$ with carboxylic acids, catechol, and amino acids having O- and $\mathrm{N}$-functional groups typical of natural organic matter were determined from solubility, in situ potentiometry and X-ray absorption fine structure spectroscopy measurements (Anderegg and Malik, 1970; Filella and May, 2005; Tella and Pokrovski, 2009, 2012; Tserenpil and Liu, 2011). However, the effect of organic ligands on the dissolution rate of antimony oxides is unknown.

The aim of the present work is to investigate the possible effects of common low-molecular-weight dissolved organic matters on the dissolution kinetics of $\mathrm{Sb}_{2} \mathrm{O}_{3}$ over an environmentally representative $\mathrm{pH}$ range and at different dosage levels. The present work, as part of a broader study of the dissolution behavior of antimony minerals, can help clarify the geochemical cycle and fate of Sb in the environment.

\section{Materials and methods}

\subsection{Organic matters}

Common low-molecular-weight dissolved organic matters (oxalic acid, citric acid, tartaric acid, EDTA, salicylic acid, phthalandione, glycine, thiolactic acid, xylitol, glucose and catechol) were selected. They exhibit a wide range of molecular structures that could affect their coordination chemistry with surface-bound and aqueous-phase metals (Furrer and Stumm, 1986), and acidity constants that span a wide range (Table 1). In the experiments on the effect of $\mathrm{pH}$, the concentration of the eleven ligands was adjusted to $1 \mathrm{mmol} / \mathrm{L}$. To study the effect of ligand dosages, their concentrations were increased to $5 \mathrm{mmol} / \mathrm{L}$ and $10 \mathrm{mmol} / \mathrm{L}$. All organic matters were purchased from Sinopharm Chemical Reagent Beijing Co. Ltd. (Beijing, China). All reagents used were analytically pure grade or better.

Table 1 - Organic ligands used in this study and stepwise dissociation constants (pK) of their functional groups and stability constants of $\mathrm{Sb}(\mathrm{III})$-ligand complexes $\left(\log \beta_{n}\right)$.

\begin{tabular}{|c|c|c|c|}
\hline Ligands & Acidity constants & $\begin{array}{l}\text { Stability constants of } \\
\text { Sb(III)-ligand complexes }\end{array}$ & References \\
\hline \multirow[t]{2}{*}{ Oxalic acid $\left(\mathrm{H}_{2} \mathrm{~L}\right)$} & $\mathrm{pK}_{1}\left(\mathrm{CO}_{2} \mathrm{H}\right)=1.40$ & $\mathrm{Sb}(\mathrm{OH})_{2} \mathrm{Oxa}^{-}(3.8 \pm 0.2)$ & Neaman et al. (2006). Tella and Pokrovski (2009) \\
\hline & $\mathrm{pK}_{2}\left(\mathrm{CO}_{2} \mathrm{H}\right)=4.26$ & $\mathrm{Sb}(\mathrm{Oxa}) \overline{2}(5.9 \pm 0.1)$ & \\
\hline \multirow[t]{4}{*}{ Citric acid $\left(\mathrm{H}_{3} \mathrm{~L}\right)$} & $\mathrm{pK}_{1}\left(\mathrm{CO}_{2} \mathrm{H}\right)=3.13$ & $\mathrm{Sb}(\mathrm{OH})_{2}(\mathrm{HCit})^{2-}(0.1 \pm 0.2)$ & Neaman et al. (2006), Tella and Pokrovski (2009) \\
\hline & $\mathrm{pK}_{2}\left(\mathrm{CO}_{2} \mathrm{H}\right)=4.76$ & $\mathrm{Sb}(\mathrm{OH})_{2}\left(\mathrm{H}_{2} \mathrm{Cit}\right)^{-}(4.6 \pm 0.3)$ & \\
\hline & $\mathrm{pK}_{3}\left(\mathrm{CO}_{2} \mathrm{H}\right)=6.40$ & $\mathrm{Sb}\left(\mathrm{H}_{2} \mathrm{Cit}\right)_{2}^{-}(-3.9 \pm 0.3)$ & \\
\hline & $\mathrm{pK}_{4}(\mathrm{OH}) \sim 16$ & & \\
\hline \multirow[t]{4}{*}{ Tartaric acid $\left(\mathrm{H}_{4} \mathrm{Tar}\right)$} & $\mathrm{pK}_{1}\left(\mathrm{CO}_{2} \mathrm{H}\right)=3.04$ & $\mathrm{SbTar}^{+}(9.855)$ & Tella and Pokrovski (2009), Filella and May (2005) \\
\hline & $\mathrm{pK}_{2}\left(\mathrm{CO}_{2} \mathrm{H}\right)=4.37$ & $\mathrm{SbTar}^{2-}(17.184)$ & \\
\hline & $\mathrm{pK}_{3}(\mathrm{COH}) \sim 14.0$ & $\mathrm{SbTar}(\mathrm{OH})^{-}(9.408)$ & \\
\hline & $\mathrm{pK}_{4}(\mathrm{COH}) \sim 15.5$ & $\mathrm{Sb}_{2} \mathrm{H}_{-2}(\mathrm{OH})_{2} \mathrm{Tar}_{2}^{2-}(22.17)$ & \\
\hline \multirow[t]{4}{*}{ EDTA $\left(\mathrm{H}_{4} \mathrm{~L}\right)$} & $\mathrm{pK}_{1}\left(\mathrm{CO}_{2} \mathrm{H}\right)=2.0$ & $\operatorname{SbEDTA}^{-}(26.77)$ & Filella and May (2005) \\
\hline & $\mathrm{pK}_{2}\left(\mathrm{CO}_{2} \mathrm{H}\right)=2.7$ & SbHEDTA $(28.00)$ & \\
\hline & $\mathrm{pK}_{3}\left(\mathrm{CO}_{2} \mathrm{H}\right)=6.1$ & $\operatorname{SbEDTA}(\mathrm{OH})^{2-}(20.760)$ & \\
\hline & $\mathrm{pK}_{4}\left(\mathrm{CO}_{2} \mathrm{H}\right) \sim 10.2$ & $\mathrm{SbEDTA}(\mathrm{OH})_{2}^{3-}(12.676)$ & \\
\hline \multirow[t]{2}{*}{ Phthalic acid $\left(\mathrm{H}_{2} \mathrm{~L}\right)$} & $\mathrm{pK}_{1}\left(\mathrm{CO}_{2} \mathrm{H}\right)=2.95$ & - & Neaman et al. (2006) \\
\hline & $\mathrm{pK}_{2}\left(\mathrm{CO}_{2} \mathrm{H}\right)=5.41$ & & \\
\hline \multirow[t]{2}{*}{ Salicylic acid $\left(\mathrm{H}_{2} \mathrm{~L}\right)$} & $\mathrm{pK}_{1}\left(\mathrm{CO}_{2} \mathrm{H}\right)=2.97$ & - & Neaman et al. (2006) \\
\hline & $\mathrm{pK}_{2}(\mathrm{OH})=13.7$ & & \\
\hline \multirow[t]{2}{*}{ Glycine (HGly) } & $\mathrm{pK}_{1}\left(\mathrm{CO}_{2} \mathrm{H}\right)=2.34$ & $\mathrm{SbGly}^{2+}(11.240)$ & Tella and Pokrovski (2009), Filella and May (2005) \\
\hline & $\mathrm{pK}_{2}\left(\mathrm{NH}_{3}\right)=9.58$ & & \\
\hline \multirow[t]{2}{*}{ Thiolactic acid $\left(\mathrm{H}_{2}\right.$ ThLac) } & $\mathrm{pK}_{1}\left(\mathrm{CO}_{2} \mathrm{H}\right)=3.63$ & $\operatorname{SbLac}^{2+}(8.717)$ & Filella and May (2005) \\
\hline & $\mathrm{pK}_{2}(\mathrm{SH})=10.24$ & $\operatorname{SbLac}_{2}^{+}(13.476)$ & \\
\hline Xylitol (Xyl) & $\mathrm{pK}(\mathrm{OH})=13.7$ & - & $\mathrm{Wu}$ and $\mathrm{Ke}(1986)$ \\
\hline Glucose & $\mathrm{pK}(\mathrm{OH})=12.43$ & - & Dean (1973) \\
\hline \multirow[t]{2}{*}{ Catechol $\left(\mathrm{H}_{2} \mathrm{~L}\right)$} & $\mathrm{pK}_{1}(\mathrm{OH})=9.45$ & SbCat $(\mathrm{OH})^{0}(3.119)$ & Tella and Pokrovski (2009), Filella and May (2005) \\
\hline & $\mathrm{pK}_{2}(\mathrm{OH})=13.0$ & $\mathrm{SbCat}_{2}^{-}(0.543)$ & \\
\hline
\end{tabular}




\subsection{Methods}

The antimony trioxide $\left(\mathrm{Sb}_{2} \mathrm{O}_{3}\right)(99.999 \%)$ used, with specific surface area $0.873 \mathrm{~m}^{2} / \mathrm{g}$, has been described in our previous study ( $\mathrm{Hu}$ et al., 2014). Rates of dissolution of $\mathrm{Sb}_{2} \mathrm{O}_{3}$ were measured in $500 \mathrm{~mL}$ beakers in the dark. For every run, $250 \mathrm{~mL}$ buffer solution with organic matter was introduced into the reactor and an accurately weighed mass of $50 \mathrm{mg}$ $\left(7.86 \mathrm{mmol} / \mathrm{m}^{2} \mathrm{Sb}\right) \mathrm{Sb}_{2} \mathrm{O}_{3}$ was added. The solutions were stirred using a magnetic stirrer. Approximately $1 \mathrm{~mL}$ aqueous solution was taken at certain intervals for $120 \mathrm{~min}$, using disposable PP/PE syringes (Zhiyu medical equipment Co., Ltd., Shanghai, China) fitted with CME $0.22 \mu \mathrm{m}$ hydrophilic syringe filters (Jinteng Laboratory Equipment Co., Ltd., Tianjin, China). Each experiment was conducted in triplicate. The following buffering agents were used: $\mathrm{pH}$ 3.7: sulfanilic acid $\left(\mathrm{pK}_{\mathrm{a}}=3.3\right)$, pH 6.6: MES (2-(N-morpholino)-ethanesulfonic acid, $\mathrm{pK}_{\mathrm{a}}=6.2$ ) and $\mathrm{pH}$ 8.6: MOPS (3-(N-morpholino)-propanesulfonic acid, $\mathrm{pK}_{\mathrm{a}}=7.2$ ). These buffers were used because they are known to have scant tendency to form complexes with metal ions (Good et al., 1966). The total buffer concentration was $0.05 \mathrm{~mol} / \mathrm{L}$ and the $\mathrm{pH}$ was adjusted to the desired value with $1 \mathrm{~mol} / \mathrm{L} \mathrm{NaOH}$ solution using a pH meter (Sartorius (Shanghai) Trading Co., Ltd., China). The ionic strength of each solution was adjusted to $0.1 \mathrm{~mol} / \mathrm{L}$ using $\mathrm{NaClO}_{4}$. Control experiments were performed using only the buffer solutions with different $\mathrm{pHs}$. The $\mathrm{pH}$ values of the solutions were measured at the beginning and end of the experiments. No drift in $\mathrm{pH}$ was observed within experimental error; thus, only the initial $\mathrm{pH}$ value was reported for each experiment. All reagents were purchased from Sinopharm Chemical Reagent Beijing Co. Ltd. (Beijing, China). All reagents used were analytically pure grade or better.

\subsection{Analysis of $S b_{\text {tot }}$ and $\mathrm{Sb}$ (III)}

The analysis of $\mathrm{Sb}_{\text {tot }}$ and $\mathrm{Sb}(\mathrm{III})$, calculation of the dissolution rate of $\mathrm{Sb}_{2} \mathrm{O}_{3}$ and normalization of the total released amount $\mathrm{Sb}_{\text {tot }}$ with respect to the specific surface area of $\mathrm{Sb}_{2} \mathrm{O}_{3}$ refer to our previous method (Hu et al., 2014). For all experiments, the concentration of $\mathrm{Sb}_{\text {tot }}$ was almost equal to the corresponding concentration of $\mathrm{Sb}$ (III) in the solution, so we only provide the concentration of $\mathrm{Sb}_{\text {tot }}$ in the subsequent sections.

\section{Results and discussion}

\subsection{Ligand trends on release rate of $\mathrm{Sb}$ at different $\mathrm{pH}$}

The release of antimony in the solution was linear during the first $60 \mathrm{~min}$, followed by a parabolic rate law after $60 \mathrm{~min}$ for some ligands (EDTA, thiolactic acid and catechol). In the subsequent discussion, the dissolution rate of $\mathrm{Sb}_{2} \mathrm{O}_{3}$ was evaluated using the concentration of mobilized antimony in the linear range from 0 to 60 min only (Table 2).

Strikingly, at $\mathrm{pH}$ 3.7, the promotion effect observed for the aliphatic ligands decreased in the order: EDTA > tartaric acid > thiolactic acid > citric acid > oxalic acid after $100 \mathrm{~min}$, but the aromatic ligands had little effect on the release of Sb (Fig. 1a). After 60 min reaction, the amount of Sb was almost unchanged in the EDTA and thiolactic acid solutions, while it still increased linearly in the tartaric acid solution even after $90 \mathrm{~min}$, and finally surpassed the concentration of $\mathrm{Sb}$ in the thiolactic acid solution.

The release of $\mathrm{Sb}$ at $\mathrm{pH} 6.6$ showed a different result from that at pH 3.7 (Fig. 1b). All released concentrations of Sb in the presence of ligands were lower than that at $\mathrm{pH}$ 3.7. Only thiolactic acid and catechol had a considerably larger effect on the enhancement of $\mathrm{Sb}$ release. The other ligands had little effect on the release of $\mathrm{Sb}$. In the thiolactic acid solution, similar to the results at $\mathrm{pH}$ 3.7, the release of Sb increased linearly for the first $60 \mathrm{~min}$ and then reached a plateau.

At $\mathrm{pH}$ 8.6, the trends of ligands on the release extent of Sb present an entirely different result from acidic conditions (pH 3.7 and 6.6) (Fig. 1c). Firstly, catechol and thiolactic acid had a considerably large promoting effect on the release of $\mathrm{Sb}$, but the effect of other ligands was slight. Secondly, unlike the trend of ligands at $\mathrm{pH}$ 6.6, the release rate and concentration of $\mathrm{Sb}$ in the presence of catechol were much larger than those in the thiolactic acid solution.

Furthermore, it can be found from Fig. 1d that: (1) the presence of EDTA, thiolactic acid, tartaric acid, citric acid and catechol could enhance the release of Sb, while the effect of other ligands was very slight; (2) with the increase of $\mathrm{pH}$, the release rate of $\mathrm{Sb}$ decreased sharply in the presence of EDTA, thiolactic acid and tartaric acid; (3) the release rate of $\mathrm{Sb}$

Table 2 - Dissolution rates of $\mathrm{Sb}_{2} \mathrm{O}_{3}$ in the first $60 \mathrm{~min}$ in the presence of organic acids at different pH and ligand dosage (unit: $\mathrm{mg} / \mathrm{m}^{2} / \mathrm{min}$ ).

\begin{tabular}{|c|c|c|c|c|c|}
\hline \multirow[t]{2}{*}{ Organic acids } & pH 3.7 & pH 6.6 & pH 8.6 & \multicolumn{2}{|c|}{ pH 6.6} \\
\hline & & $1 \mathrm{mmol} / \mathrm{L}$ & & $5 \mathrm{mmol} / \mathrm{L}$ & $10 \mathrm{mmol} / \mathrm{L}$ \\
\hline Ligand-free & 0.043 & 0.160 & 0.126 & 0.160 & 0.160 \\
\hline Oxalic acid & 0.060 & 0.163 & 0.134 & 0.157 & 0.163 \\
\hline Citric acid & 0.417 & 0.231 & 0.191 & 0.682 & 1.455 \\
\hline Tartaric acid & 2.537 & 0.160 & 0.157 & 0.263 & 0.442 \\
\hline EDTA & 4.806 & 0.191 & 0.154 & 0.265 & 0.525 \\
\hline Salicylic acid & 0.080 & 0.157 & 0.143 & 0.137 & 0.163 \\
\hline Phthalandione & 0.120 & 0.154 & 0.131 & 0.157 & 0.163 \\
\hline Glycine & 0.066 & 0.151 & 0.131 & 0.137 & 0.131 \\
\hline Thiolactic acid & 3.830 & 1.507 & 0.916 & 5.574 & 8.071 \\
\hline Xylitol & 0.088 & 0.143 & 0.114 & 0.160 & 0.126 \\
\hline Glucose & 0.060 & 0.163 & 0.106 & 0.148 & 0.114 \\
\hline Catechol & 0.203 & 0.531 & 2.451 & 1.926 & 2.586 \\
\hline
\end{tabular}



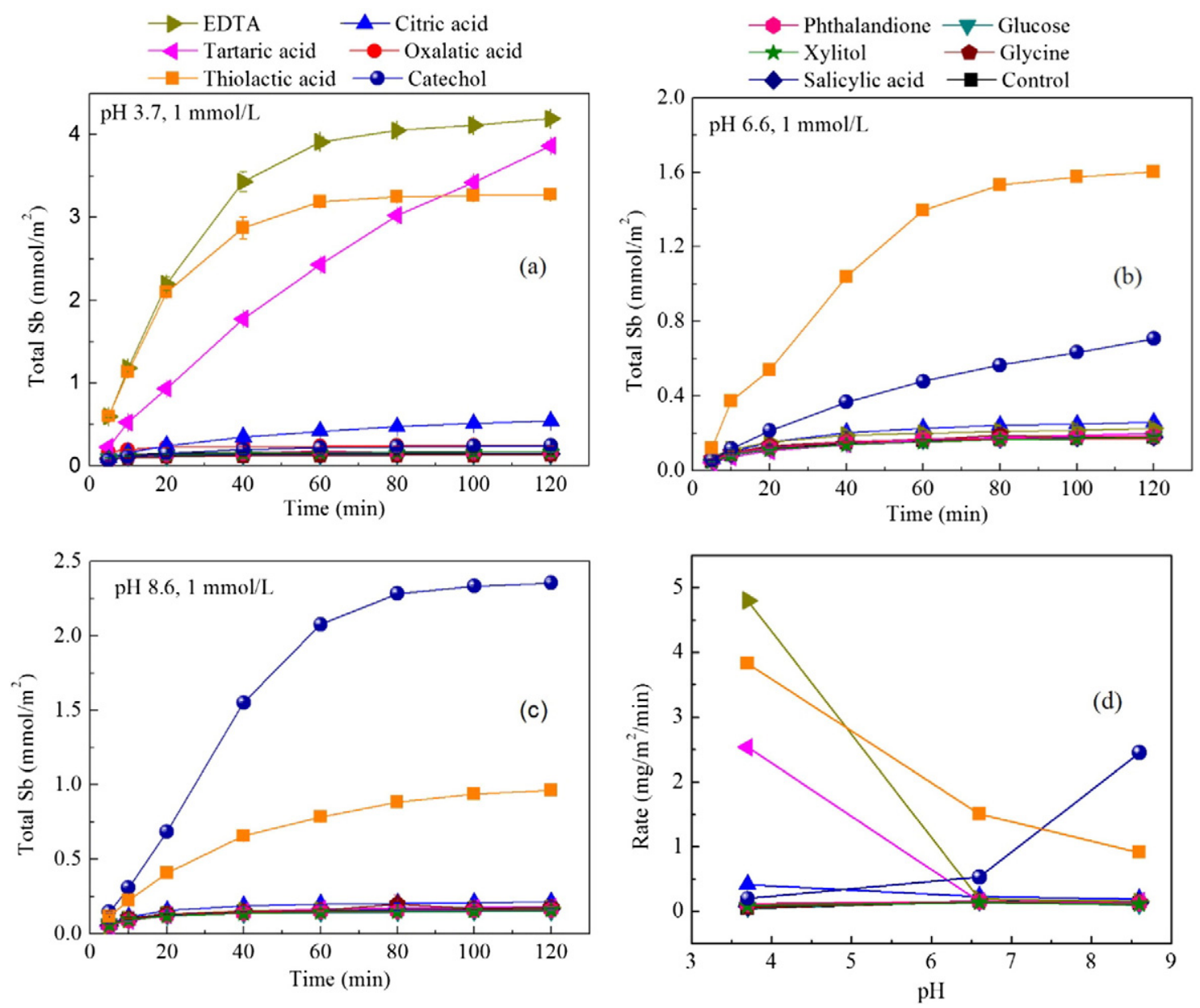

Fig. 1 - (a-c) Surface-normalized amount of $\mathrm{Sb}_{\text {tot }}$ mobilized as function of time at pH 3.7, pH 6.6 and pH 8.6 and (d) variation of dissolution rates with $\mathrm{pH}$ for various ligands.

increased sharply in the presence of catechol with the increase of $\mathrm{pH}$; (4) on the whole, the dissolution rate of $\mathrm{Sb}_{2} \mathrm{O}_{3}(4.806,3.830$ and $2.537 \mathrm{mg} / \mathrm{m}^{2} / \mathrm{min}$ ) in the EDTA, thiolactic acid and tartaric acid solutions under the acidic condition was larger than that $\left(2.451 \mathrm{mg} / \mathrm{m}^{2} / \mathrm{min}\right)$ in the catechol solution under the alkaline condition. Thus, the discussion below will focus on the effects of EDTA, thiolactic acid, tartaric acid, citric acid and catechol.

\subsubsection{Effect of EDTA}

As we know, the rate of ligand-promoted dissolution is, in the general case, proportional to the surface concentration of the surface complex (Furrer and Stumm, 1986; Sposito, 2004). Both of the 1st two $\mathrm{pK}_{\mathrm{a}}$ values $\left(\mathrm{pK}_{\mathrm{a} 1}=2.0\right.$ and $\left.\mathrm{pK}_{\mathrm{a} 2}=2.7\right)$ of EDTA are below 3.0, so that at $\mathrm{pH}=3.7$, two fully and one incompletely deprotonated carboxyl group are available for multidentate chelation with Sb (Biver and Shotyk, 2012b). Moreover, the stability constant $(\log K)$ values of $\mathrm{SbEDTA}^{-}$, SbHEDTA, SbEDTA $(\mathrm{OH})^{2-}$ and $\operatorname{SbEDTA}(\mathrm{OH})_{2}^{3-}$, published as 26.77, 28.00, 20.76 and 12.68, respectively (Filella and May, 2005), are higher than the stability constants of other Sb-ligand complexes, so at pH 3.7, EDTA exhibited excellent promoting ability on the dissolution of $\mathrm{Sb}_{2} \mathrm{O}_{3}$. By contrast, a decrease in the dissolution rate was found at $\mathrm{pH} 6.6$ and 8.6. This is because $\mathrm{pH} 6.6$ is close to the $\mathrm{pH}_{\text {PZC }}=5.98$ ( $\mathrm{pH}$ at point of zero charge) of
$\mathrm{Sb}_{2} \mathrm{O}_{3}$ (Xu and Schoonen, 2000). Stumm and Morgan (1996) emphasized that the $\mathrm{pH}$-dependent surface charge of minerals is an important factor in their dissolution, because the polarization affects surface chemical bonds and causes generalized minimum dissolution rates of minerals at the $\mathrm{pH}_{\mathrm{PZC}}$. In addition, previous research on equilibria of $\mathrm{Sb}$ (III)-polyaminocarboxylic acids has shown that when $\mathrm{pH}>7$, surface precipitation would occur (Filella and May, 2005), so that little dissolved Sb could be detected in the alkaline solution.

\subsubsection{Effect of thiolactic acid}

Similar to the effect of EDTA, the rate of thiolactic acidpromoted dissolution is related to the concentration of the surface Sb-thiolactate complex. The $\mathrm{pK}_{1}\left(\mathrm{CO}_{2} \mathrm{H}\right)$ and $\mathrm{pK}_{2}(\mathrm{SH})$ of thiolactic acid are equal to 3.63 and 10.24 (Tella and Pokrovski, 2009). The studied $\mathrm{pH}$ range was 3.7-8.6, so the sulfhydryl group (- $\mathrm{SH})$ was unavailable for chelation with $\mathrm{Sb}$. Thus, the effect of thiolactic acid may be understood as analogous to the interaction between $\mathrm{Sb}(\mathrm{OH})_{3}$ and lactic acid (HLac), with $\mathrm{pK}_{1}$ $\left(\mathrm{CO}_{2} \mathrm{H}\right)=3.86$ (Neaman et al., 2006). Previous research (Tella and Pokrovski, 2009) showed that at $\mathrm{pH}<4$, a bidendate complex, $\mathrm{SbLac}_{2}^{-}$, formed according to the reaction:

$\mathrm{Sb}(\mathrm{OH})_{3}^{0}+2 \mathrm{HLac}^{-} \rightarrow 2 \mathrm{H}_{2} \mathrm{O}+\mathrm{OH}^{-}+\mathrm{SbLac}_{2}^{-}$ 
When $\mathrm{pH}>4$, in addition to $\mathrm{SbLac}_{2}^{-}, \mathrm{Sb}(\mathrm{OH}) \mathrm{Lac}_{2}^{-}$also formed according to the reaction below:

$\mathrm{Sb}(\mathrm{OH})_{3}^{0}+\mathrm{HLac}^{-} \rightarrow \mathrm{H}_{2} \mathrm{O}+\mathrm{Sb}(\mathrm{OH})_{2} \mathrm{Lac}^{-}$

In addition, the dosage of thiolactic acid was found to have an important influence on the release rate of $\mathrm{Sb}$. When the concentration of thiolactic acid increased to 5 and 10 from $1 \mathrm{mmol} / \mathrm{L}$, the release rate of Sb increased to 5.574 and 8.071 from $1.507 \mathrm{mg} / \mathrm{m}^{2} / \mathrm{min}$. Thus, as the $\mathrm{pH}$ increased, the free thiolactic acid concentration (undeprotonated carboxyl group) decreased, fewer surface complexes of Sb-thiolactic acid were formed, and the dissolution rate of $\mathrm{Sb}_{2} \mathrm{O}_{3}$ was weakened.

\subsubsection{Effect of tartaric acid}

The $\mathrm{pH}$-dependent trend in the tartaric acid $\left(\mathrm{H}_{2} \mathrm{Tar}\right)$ solution is the same as the case of EDTA: $\mathrm{pH}$ has a great effect on the dissolution rate of $\mathrm{Sb}_{2} \mathrm{O}_{3}$ under the acidic condition because of large stability constants of Sb-Tar ${ }^{2-}$ complexes formed in Eqs. (3)-(7) (Filella and May, 2005), but almost no effect on the release of $\mathrm{Sb}$ at $\mathrm{pH} 6.6$ and 8.6. In addition to above-mentioned reasons for the effect of EDTA and thiolactic acid on the release rate of $\mathrm{Sb}$, as a multidentate chelator at $\mathrm{pH}=6.6$ and 8.6 (Tella and Pokrovski, 2009), the steric hindrance effect of Sb-tartaric acid complexes might be also a main factor.

$$
\begin{aligned}
& \mathrm{Sb}(\mathrm{OH})_{3}^{0}+3 \mathrm{H}^{+}+\mathrm{Tar}^{2-} \rightarrow 3 \mathrm{H}_{2} \mathrm{O}+\mathrm{SbTar}^{+} \\
& \mathrm{Sb}(\mathrm{OH})_{3}^{0}+3 \mathrm{H}^{+}+2 \mathrm{Tar}^{2-} \rightarrow 3 \mathrm{H}_{2} \mathrm{O}+\mathrm{SbTar}^{2-} \\
& \mathrm{Sb}(\mathrm{OH})_{3}^{0}+2 \mathrm{H}^{+}+\mathrm{Tar}^{2-} \rightarrow 2 \mathrm{H}_{2} \mathrm{O}+\operatorname{SbTar}(\mathrm{OH})^{-} \\
& \mathrm{Sb}(\mathrm{OH})_{3}^{0}+2 \mathrm{H}^{+}+2 \mathrm{Tar}^{2-} \rightarrow 4 \mathrm{H}_{2} \mathrm{O}+\mathrm{Sb}_{2} \mathrm{H}_{-2}(\mathrm{OH})_{2} \operatorname{Tar}_{2}^{2-} \\
& \mathrm{Sb}(\mathrm{OH})_{3}^{0}+\operatorname{Tar}^{2-} \rightarrow 2 \mathrm{H}_{2} \mathrm{O}+\mathrm{SbH}_{-2}(\mathrm{OH}) \mathrm{Tar}^{2-}
\end{aligned}
$$

\subsubsection{Effect of citric acid}

Citric acid has only a slight effect on the release of Sb. The $\mathrm{pH}$-dependent trend is the same as the case of the above ligands: a promoting effect at $\mathrm{pH} 3.7$, a retarding effect at $\mathrm{pH}=6.6$ and little effect in basic solution. According to the complex model, however, at $\mathrm{pH}=6.6$ and 8.6 the third protolysis of citric acid is almost complete $\left(\mathrm{pK}_{\mathrm{a} 1}=3.16\right.$, $\mathrm{pK}_{\mathrm{a} 2}=4.76$ and $\mathrm{pK}_{\mathrm{a} 3}=6.40$ ) (Tella and Pokrovski, 2009), so that it should act as a multidentate chelator and promote the release of Sb. All the above is ascribed to the concentration of the surface Sb-citrate complex (Eqs. (8)-(10) (Tella and Pokrovski, 2009), the free citric acid concentration and the $\mathrm{pH}_{\mathrm{PZC}}$ of $\mathrm{Sb}_{2} \mathrm{O}_{3}$. At $\mathrm{pH}$ 3.7, more deprotonated citric acid was consumed, and more Sb-citrate complexes were formed than those at other $\mathrm{pH}$ values, so more $\mathrm{Sb}$ was released. At $\mathrm{pH}=6.6$, just as with EDTA, the impact of the $\mathrm{pH}_{\mathrm{PZC}}$ of $\mathrm{Sb}_{2} \mathrm{O}_{3}$ played a decisive role. In the alkaline solution, surface precipitation would occur (Filella and May, 2005), so that little dissolved Sb was detected.

$$
\begin{aligned}
& \mathrm{Sb}(\mathrm{OH})_{3}^{0}+\mathrm{H}_{3} \mathrm{Cit}^{-} \rightarrow \mathrm{H}_{2} \mathrm{O}+\mathrm{H}^{+}+\mathrm{Sb}(\mathrm{OH})_{2}(\mathrm{Cit})^{2-} \\
& \mathrm{Sb}(\mathrm{OH})_{3}^{0}+\mathrm{H}_{3} \mathrm{Cit}^{-} \rightarrow \mathrm{H}_{2} \mathrm{O}+\mathrm{Sb}(\mathrm{OH})_{2}\left(\mathrm{H}_{2} \mathrm{Cit}\right)^{-} \\
& \mathrm{Sb}(\mathrm{OH})_{3}^{0}+2 \mathrm{H}_{3} \mathrm{Cit}^{-} \rightarrow \mathrm{Sb}\left(\mathrm{H}_{2} \mathrm{Cit}\right)_{2}^{-}+\mathrm{H}_{2} \mathrm{O}+\mathrm{OH}^{-}
\end{aligned}
$$

\subsubsection{Effect of catechol}

The presence of catechol $\left(\mathrm{H}_{2} \mathrm{Cat}\right)$ inhibits the release of $\mathrm{Sb}$ at pH 3.7 and pH 6.6, while accelerating it at pH 8.6. A possible reason for this lies in the relatively high $\mathrm{pK}_{\mathrm{a} 1}$ of the 1 st (phenolic) deprotonation of catechol $\left(\mathrm{pK}_{\mathrm{a} 1}=9.45\right)$ (Tella and Pokrovski, 2009). At $\mathrm{pH}=8.7$, at least part of the chelating functional groups are deprotonated, so that catechol can develop its chelating ability when the 1 st $\mathrm{pK}_{\mathrm{a}}$ is approached. The chelating reaction between $\mathrm{Sb}(\mathrm{OH})_{3}$ and catechol can be written as:

$\mathrm{Sb}(\mathrm{OH})_{3}^{0}+2 \mathrm{H}_{2} \mathrm{Cat} \rightarrow 3 \mathrm{H}_{2} \mathrm{O}+\mathrm{H}^{+}+\mathrm{SbCat}_{2}^{-}$

As suggested by Filella and May (2005), and the stability constant (logK) value of SbCat ${ }_{2}^{-}$is 5.44 (Anderegg and Malik, 1970). According to Eq. (11), with the increase of $\mathrm{pH}$, the reaction shifted to the right and then more $\mathrm{Sb}_{2} \mathrm{O}_{3}$ dissolved. At $\mathrm{pH} 3.7$ and 6.6, catechol seems to act as a monodentate ligand with a decelerating effect on the dissolution rate. In addition to the effect of the $\mathrm{pH}_{\text {PZC }}$ (5.98) of $\mathrm{Sb}_{2} \mathrm{O}_{3}$ and the concentration of free ligand, as pointed out by Furrer and Stumm (1986), monodentate ligands frequently have no effect on or even retard dissolution by blocking access to the surface.

\subsubsection{Effects of other ligands}

The other organic ligands had virtually no effect on the release of $\mathrm{Sb}$ in the studied $\mathrm{pH}$ range (3.7-8.6) in spite of having greater complex stability constants with $\mathrm{Sb}$ (III). For example, the complex stability constant of glycine with $\mathrm{Sb}\left(\mathrm{SbGly}^{2+}\right)$ is 11.24 (Filella, and May, 2005), which is much larger than that of the catechol-Sb complex $\left(\mathrm{SbCat}(\mathrm{OH})^{9}\right)(\log \mathrm{K}=3.119)$. However, the former ligands showed a considerably smaller effect on the enhancement of release of $\mathrm{Sb}$ in comparison to the latter ligands.

\subsection{Ligand trends on release rate of $\mathrm{Sb}$ at different dosages}

The increase of ligand dosage, such as for thiolactic acid, catechol, citric acid, EDTA and tartaric acid, enhanced the dissolution rate of $\mathrm{Sb}_{2} \mathrm{O}_{3}$ (Fig. 2), especially in the thiolactic acid, catechol, and citric acid solutions. When the dosage of

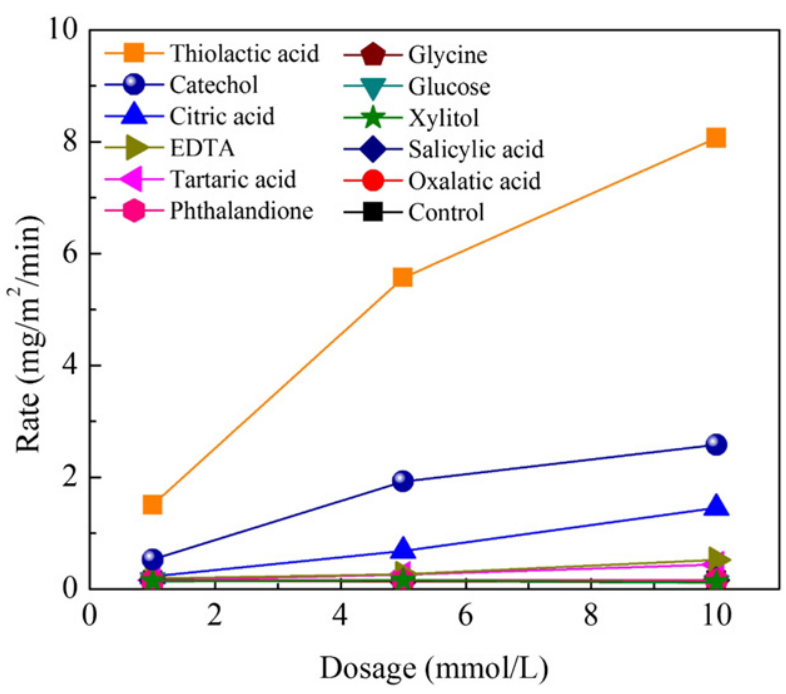

Fig. 2 - Ligand trends in which the dissolution rates vary monotonically with the dosage of various ligands. 
thiolactic acid increased to 5 and $10 \mathrm{mmol} / \mathrm{L}$, the release rate of Sb was 4 times and 6 times greater, respectively, than that in the $1 \mathrm{mmol} / \mathrm{L}$ thiolactic acid solution, which was the case for catechol and citric acid as well. These results illustrated that the dissolution rate of $\mathrm{Sb}_{2} \mathrm{O}_{3}$ was related to the ligand concentration. With increasing ligand dosage, more dissolved $\mathrm{Sb}$ was chelated, which then promoted the dissolution of $\mathrm{Sb}_{2} \mathrm{O}_{3}$. However, the increase ratio of the dissolution rate was found to be less than the increase ratio of the ligand dosage. This could be due to steric hindrance, which could occur when a high concentration of LMWDOMs were adsorbed to the surface of $\mathrm{Sb}_{2} \mathrm{O}_{3}$. Meanwhile, this also could explain why the release rate of $\mathrm{Sb}$ in the $1 \mathrm{mmol} / \mathrm{L}$ thiolactic acid solution was larger in the first $60 \mathrm{~min}$ than that at 60-120 min. This occurred because the depletion of limited thiolactic acid over time resulted in insufficient ligand concentration for chelation with $\mathrm{Sb}$ (III) at 60-120 min, which was true for catechol as well. In addition, all the results illustrated that in the case of thiolactic acid, catechol and citric acid, the dosage exhibited a considerably larger effect on the enhancement of release of $\mathrm{Sb}$ from $\mathrm{Sb}_{2} \mathrm{O}_{3}$ compared with the effect of $\mathrm{pH}$.

\subsection{Ligand trends on release percentage of $\mathrm{Sb}$}

The release percentage of $\mathrm{Sb}$ to the total $\mathrm{Sb}$ contained in the original $\mathrm{Sb}_{2} \mathrm{O}_{3}$ at the end of the experiment under different conditions is summarized in Table 3. On the one hand, generalizing for $\mathrm{pH} 3$, the promoting effect and extent of dissolution observed for the aliphatic ligands decreased in the order: EDTA > tartaric acid > thiolactic acid > citric acid > oxalic acid, but the aromatic ligands had only a slight effect on release. With the increase of $\mathrm{pH}$ (pH 6.6 and 8.6), the promoting effect and extent of dissolution for the aliphatic ligands was lessened on the whole compared to that at $\mathrm{pH}$ 3.7. For catechol, the release percentage of $\mathrm{Sb}(3.15 \%, 9.00 \%$ and $30.0 \%$ at $\mathrm{pH} 3.0,6.6$ and 8.6, respectively) increased noticeably with the increase of $\mathrm{pH}$. Generalizing for increasing ligand dosage (5 and $10 \mathrm{mmol} / \mathrm{L}$ ), a promoting effect on dissolution was observed for all ligands and decreased in the order: thiolactic acid $>$ catechol $>$ citric acid > EDTA. On the other hand, the release percentage of $\mathrm{Sb}$ increased from $20.4 \%, 9.00 \%$ and $3.29 \%$ to $97.0 \%, 59.8 \%$ and $22.3 \%$ when the dosage of thiolactic acid, catechol and citric acid increased from 1 to $10 \mathrm{mmol} / \mathrm{L}$ at $\mathrm{pH}$ 6.6, respectively. That is,

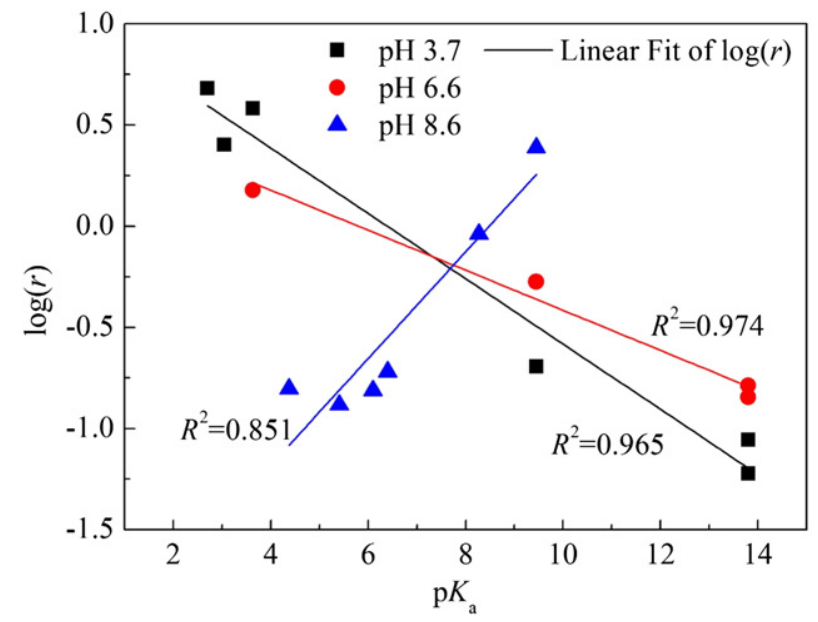

Fig. 3 - Correlation between logarithms of measured ligandpromoted dissolution rates and $\mathrm{pK}_{\mathrm{a}}$ values of some ligands.

almost all Sb was released from $\mathrm{Sb}_{2} \mathrm{O}_{3}$ in the $10 \mathrm{mmol} / \mathrm{L}$ thiolactic acid solution. All the above results are explained by the effect of $\mathrm{pH}$ and dosage on the dissolution rate of $\mathrm{Sb}_{2} \mathrm{O}_{3}$ in the presence of ligands.

\subsection{Correlation of acid dissociation constants and extent of complexation with dissolution rate}

In some cases, there is a correlation between the $\log (r)$ and the $\mathrm{pK}_{\mathrm{a}}$ of the dissociation step of a polyprotic acid believed to be relevant for complex formation, irrespective of whether the ligand exerts a promotive or an inhibitory effect (Biver and Shotyk, 2012b; Ludwig et al., 1995). In this study, the $\log (r)$ shows a linear dependence on the $\mathrm{pK}_{\mathrm{a}}$ in the six organic ligand solutions (Fig. 3), which suggests a potential relationship between the rate of ligand-promoted dissolution and the acid dissociation constants of the organic ligands (Eqs. (12)-(14)). The result confirmed the relationship between the dissolution rate of $\mathrm{Sb}_{2} \mathrm{O}_{3}$ and the dissociation of polyprotic acids. This is also consistent with most studies on the effects of ligands on dissolution rates of (hydr-) oxides: the rate of ligand-promoted dissolution $(r)$ is proportional to the surface concentration of the surface complex. As we know, the surface concentration of a

Table 3 - Release percentage (wt\%) of Sb at the end of experiments in the presence of various ligands at different $\mathrm{pH}$ and ligand dosage.

\begin{tabular}{|c|c|c|c|c|c|}
\hline \multirow[t]{2}{*}{ Organic ligands } & pH 3.7 & pH 6.6 & pH 8.6 & \multicolumn{2}{|c|}{ pH 6.6} \\
\hline & & $1 \mathrm{mmol} / \mathrm{L}$ & & $5 \mathrm{mmol} / \mathrm{L}$ & $10 \mathrm{mmol} / \mathrm{L}$ \\
\hline Ligand-free & 2.18 & 2.23 & 2.20 & 2.23 & 2.23 \\
\hline Oxalic acid & 3.16 & 2.21 & 2.19 & 2.66 & 2.53 \\
\hline Citric acid & 6.90 & 3.29 & 2.73 & 9.74 & 22.3 \\
\hline Tartaric acid & 49.2 & 2.55 & 2.30 & 4.65 & 6.14 \\
\hline EDTA & 53.4 & 2.85 & 2.20 & 4.26 & 9.63 \\
\hline Salicylic acid & 1.90 & 2.28 & 2.13 & 2.23 & 2.56 \\
\hline Phthalandione & 2.19 & 2.38 & 2.07 & 2.81 & 2.60 \\
\hline Glycine & 1.69 & 2.34 & 2.26 & 2.13 & 2.52 \\
\hline Thiolactic acid & 41.7 & 20.4 & 12.3 & 82.9 & 97.0 \\
\hline Xylitol & 2.18 & 2.29 & 2.03 & 3.02 & 2.10 \\
\hline Glucose & 1.76 & 2.35 & 1.96 & 2.17 & 2.31 \\
\hline Catechol & 3.15 & 9.00 & 30.0 & 40.1 & 59.8 \\
\hline
\end{tabular}




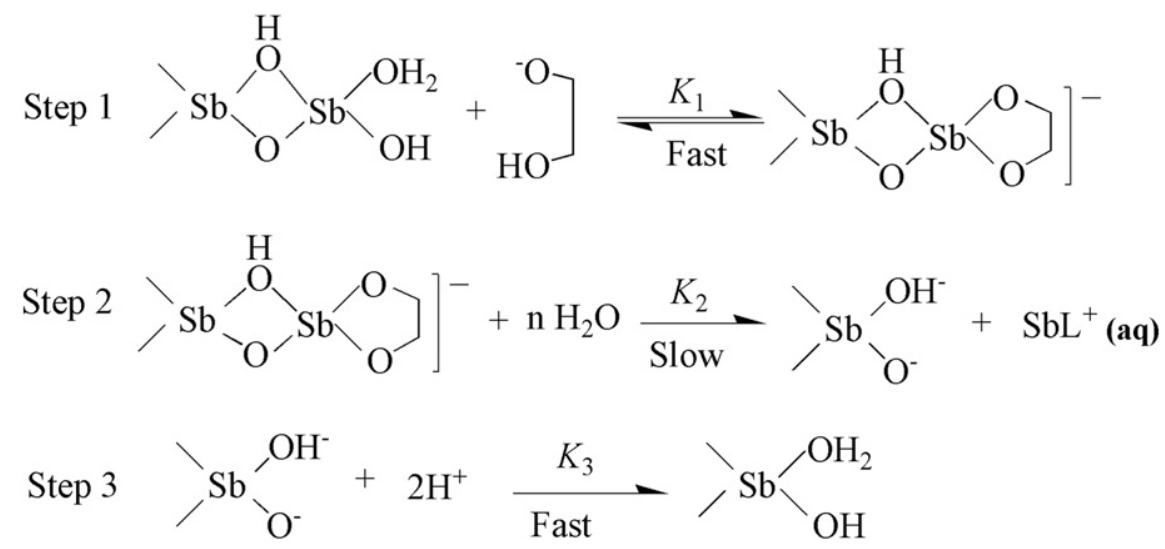

Fig. 4 - Ligand-promoted dissolution processes of $\mathrm{Sb}_{2} \mathrm{O}_{3} . \mathrm{SbL}^{+}$refers to a series of $\mathrm{Sb}$ and low weight dissolved organic matter complexes.

complex is related to the solution phase concentration of the ligand via an adsorption isotherm. Thus, ultimately, the ligandinduced dissolution rate of $\mathrm{Sb}_{2} \mathrm{O}_{3}$ has a relationship with the solution-phase concentration of the ligand.

pH 3.7: $\quad \log (r)=-0.161 p K_{a}+1.03\left(R^{2}=0.965\right)$

pH 6.6: $\quad \log (r)=-0.098 p K_{a}+0.574\left(R^{2}=0.974\right)$

pH 8.6: $\quad \log (r)=0.263 p K_{a}-2.24\left(R^{2}=0.851\right)$

However, no correlation between the extent of complexation in solution and the reaction rate was found. For instance, nearly all of the Sb present in solution was complexed by EDTA, oxalate and citrate under the conditions of the experiments; however, the dissolution rates and the observed trends of the rates as a function of $\mathrm{pH}$ differed widely for these three ligands. The simple principle of a correlation between dissolution rate and the stability of the dissolved complex (Ludwig et al., 1995) may not be generally applicable: the concept of the similarity between the surface complex and the aqueous complex present in solution, for instance, does not at all take into account the possibility of surface passivation resulting from polynuclear surface complexes, which may be of similar stability as the aqueous complexes, but quite reluctant to detach from the surface (Furrer and Stumm, 1986). Mechanistically, the ligand-promoted dissolution process of $\mathrm{Sb}_{2} \mathrm{O}_{3}$ (Fig. 4) can be deduced from the bioxalate ligand on a trivalent metal oxide (Furrer and Stumm, 1986): the first step is the reversible, rapid formation of a surface chelate, which in step 2 (the slow, rate-determining step) is detached by nucleophilic attack of water. Step 3 represents the rapid reprotonation of the fresh layer. The $\mathrm{pK}_{\mathrm{a}}$ value of a ligand and stability constant of the Sb-ligand complex are key factors in the formation of a surface chelate, but not decisive factors in promoting the dissolution of $\mathrm{Sb}_{2} \mathrm{O}_{3}$. Ultimately, the detachment rate of the surface chelate dominates the dissolution of $\mathrm{Sb}_{2} \mathrm{O}_{3}$.

\section{Conclusions}

The effect of low-molecular-weight dissolved organic matter on the dissolution of $\mathrm{Sb}_{2} \mathrm{O}_{3}$ is part of a broader study of the dissolution behavior of antimony oxide minerals. EDTA, tartaric acid, thiolactic acid, citric acid and oxalic acid as multidentate ligands have an overall promotive effect under acidic conditions, while catechol has an overall promotive effect under alkaline conditions. Comparing the dissolution rate of $\mathrm{Sb}_{2} \mathrm{O}_{3}$ with the initial dissolution rates of $\mathrm{Sb}_{2} \mathrm{~S}_{3}$ in the presence of $1 \mathrm{mmol} / \mathrm{L}$ catechol, citrate and EDTA (Biver and Shotyk, 2012a), we found the values of dissolution rates of $\mathrm{Sb}_{2} \mathrm{O}_{3}$ and $\mathrm{Sb}_{2} \mathrm{~S}_{3}$ were of the same order of magnitude $\left(10^{-5} \mathrm{~mol} / \mathrm{m}^{2} / \mathrm{min}\right)$. Also, the trend of $\mathrm{pH}$-dependent dissolution rates in the presence of the above ligands was similar between $\mathrm{Sb}_{2} \mathrm{O}_{3}$ and $\mathrm{Sb}_{2} \mathrm{~S}_{3}$. In addition, we found that the effect of some ligands on the dissolution of $\mathrm{Sb}_{2} \mathrm{O}_{3}$ was much larger than the effect of light at a similar pH level (Hu et al., 2014). Some ligands, such as EDTA, thiolactic acid, tartaric acid, citric acid and catechol have more influence on the dissolution rates of $\mathrm{Sb}_{2} \mathrm{O}_{3}$ than those at acidic $\mathrm{pH}$ values in the presence of light. A linear dependence of the logarithm $(\mathrm{r})$ on $\mathrm{pK}_{\mathrm{a}}$ was found for the six organic ligands, suggesting a potential relationship between the rate of ligand-promoted dissolution of $\mathrm{Sb}_{2} \mathrm{O}_{3}$ and acid dissociation constants of the organic ligands. No correlation was found between the complexation extent of Sb-ligands in solution and the release rate of $\mathrm{Sb}$. In conclusion, the promotive extent of ligands on the dissolution of $\mathrm{Sb}_{2} \mathrm{O}_{3}$ was determined by the detachment rate of surface chelate from the mineral surface. These results in this paper help us to further recognize the geochemical implications of $\mathrm{Sb}$. The effect of natural organic matters on the dissolution of $\mathrm{Sb}_{2} \mathrm{O}_{3}$ will be studied in future work.

\section{Acknowledgments}

This work was supported by the National Natural Science Foundation of China (No. 41273105).

\section{R E F E R E N C E S}

Aiken, G.R., Hsu-Kim, H., Ryan, J.N., 2011. Influence of dissolved organic matter on the environmental fate of metals, nanoparticles, and colloids. Environ. Sci. Technol. 45 (8), 3196-3201.

Amarasiriwardena, D., Wu, F.C., 2011. Antimony: emerging toxic contaminant in the environment preface. Microchem. J. 97 (1SI), 1-3. 
Anderegg, G., Malik, S., 1970. Die Komplexbildungstendenz des dreiwertigen Antimons in wässriger Lösung. Helv. Chim. Acta 53, 577-600.

Biber, M.V., Dos Santos Afonso, M., Stumm, W., 1994. The coordination chemistry of weathering: IV. Inhibition of the dissolution of oxide minerals. Geochim. Cosmochim. Acta 58 (9), 1999-2010.

Biver, M., Shotyk, W., 2012a. Stibnite $\left(\mathrm{Sb}_{2} \mathrm{~S}_{3}\right)$ oxidative dissolution kinetics from pH 1 to 11. Geochim. Cosmochim. Acta 79 (3), 127-139.

Biver, M., Shotyk, W., 2012b. Experimental study of the kinetics of ligand-promoted dissolution of stibnite $\left(\mathrm{Sb}_{2} \mathrm{~S}_{3}\right)$. Chem. Geol. 294-295 (4), 165-172.

Biver, M., Shotyk, W., 2013. Stibiconite $\left(\mathrm{Sb}_{3} \mathrm{O}_{6} \mathrm{OH}\right)$, senarmontite $\left(\mathrm{Sb}_{2} \mathrm{O}_{3}\right)$ and valentinite $\left(\mathrm{Sb}_{2} \mathrm{O}_{3}\right)$ : dissolution rates at $\mathrm{pH}$ 2-11 and isoelectric points. Geochim. Cosmochim. Acta 109 (3), 268-279.

Brantley, S.L., 2008. Kinetics of Mineral Dissolution. Springer Publishing, New York, pp. 151-210.

Council of the European Communities, 1976. Council directive76r464-rEEC of 4 May 1976 on pollution caused by certain dangerous substances discharged into the aquatic environment of the community. Off. J. L 129 (18r05r1976), 23-29.

Davis, A.P., Hsieh, Y.H., Huang, C.P., 1995. Photo-oxidative dissolution of CdS(s): the effect of complexing agents. Chemosphere 31 (4), 3093-3104.

Dean, J.A., 1973. Lange's Handbook of Chemistry. 11th Edition. McGraw-Hill, New York.

Filella, M., May, P.M., 2005. Critical appraisal of available thermodynamic data for the complexation of antimony (III) and antimony (V) by low molecular mass organic ligands. J. Environ. Monit. 7 (12), 1226-1237.

Filella, M., Williams, P.A., Belzile, N., 2009. Antimony in the environment: knowns and unknowns. Environ. Chem. 6 (2), 95-105.

Furrer, G., Stumm, W., 1986. The coordination chemistry of weathering: I. Dissolution kinetics of $\delta-\mathrm{Al}_{2} \mathrm{O}_{3}$ and $\mathrm{BeO}$. Geochim. Cosmochim. Acta 50 (9), 1847-1860.

Good, N.E., Winget, G.D., Winter, W., Connolly, T.N., Izawa, S., Singh, R.M., 1966. Hydrogen ion buffers for biological research. Biochemistry 5 (2), 467-477.

Gulley-Stahl, H., Hogan II, P.A., Schmidt, W.L., Wall, S.J., Buhrlage, A., Bullen, H.A., 2010. Surface complexation of catechol to metal oxides: an ATR-FTIR, adsorption, and dissolution study. Environ. Sci. Technol. 44 (44), 4116-4121.

He, M.C., Wang, X.Q., Wu, F.C., Fu, Z.Y., 2012. Antimony pollution in China. Sci. Total Environ. 421-422 (3), 41-50.

Hu, X.Y., Kong, L.H., He, M.C., 2014. Kinetics and mechanism of photopromoted oxidative dissolution of antimony trioxide. Environ. Sci. Technol. 48 (24), 14266-14272.

Hu, X.Y., He, M.C., Kong, L.H., 2015. Photopromoted oxidative dissolution of stibnite. Appl. Geochem. 61, 53-61.

Hu, X.Y., Guo, X.J., He, M.C., Li, S.S., 2016a. pH-dependent release characteristics of antimony and arsenic from typical antimony-bearing ores. J. Environ. Sci. 44 (6), 171-179.
Hu, X.Y., He, M.C., Li, S.S., Guo, X.J., 2016b. The leaching characteristics and changes in the leached layer of antimony-bearing ores from China. J. Geochem. Explor. http://dx.doi.org/10.1016/j.gexplo.2016. 01.009 .

Liang, L., Hofmann, A., Gu, B., 2000. Ligand-induced dissolution and release of ferrihydrite colloids. Geochim. Cosmochim. Acta 64 (12), 2027-2037.

Ludwig, C., Casey, W.H., Rock, P.A., 1995. Prediction of ligand-promoted dissolution rates from the reactivities of aqueous complexes. Nature 375 (6526), 621-626.

Maher, W.A., 2009. Antimony in the environment - the new global puzzle. Environ. Chem. 6 (2), 93-94.

Neaman, A., Chorover, J., Brantley, S.L., 2006. Effects of organic ligands on granite dissolution in batch experiments at pH 6 . Am. J. Sci. 306 (6), 451-473.

Reimann, C., Matschullat, J., Birke, M., Salminen, R., 2010. Antimony in the environment: lessons from geochemical mapping. Appl. Geochem. 25 (2), 175-198.

Shotyk, W., Krachler, M., Chen, B., 2005. Antimony: global environmental contaminant. J. Environ. Monit. 7 (12), 1135-1136.

Sposito, G., 2004. The Surface Chemistry of Natural Particles. Oxford University Press, Oxford/New York.

Sposito, G., 2008. The Chemistry of Soils. Oxford University Press, Oxford/New York.

Stumm, W., Morgan, J.J., 1996. Aquatic Chemistry: Chemical Equilibria and Rates in Natural Waters. third ed. John Wily \& Sons, Inc., New York, p. 1022.

Tella, M., Pokrovski, G.S., 2009. Antimony (III) complexing with O-bearing organic ligands in aqueous solution: an X-ray absorption fine structure spectroscopy and solubility study. Geochim. Cosmochim. Acta 73 (2), 268-290.

Tella, M., Pokrovski, G.S., 2012. Stability and structure of pentavalent antimony complexes with aqueous organic ligands. Chem. Geol. 292-293 (1), 57-68.

Tserenpil, S., Liu, C., 2011. Study of antimony (III) binding to soil humic acid from an antimony smelting site. Microchem. J. 98 (1), 15-20.

United States Environmental Protection Agency, 1979. Toxics Release Inventory, Doc. 745-R-00-007. USEPA, Washington, DC.

Waples, J.S., Nagy, K.L., Aiken, G.R., Ryan, J.N., 2005. Dissolution of cinnabar (HgS) in the presence of natural organic matter. Geochim. Cosmochim. Acta 69 (6), 1575-1588.

Wu, J.G., Ke, J.J., 1986. A study of interaction between lead oxides and polyhydric alcohols in alkaline solution. J. Grad. School Chin. Acad. Sci. 2, 96-103 (In Chinese).

$\mathrm{Xu}$, Y., Schoonen, M., 2000. The absolute energy positions of conduction and valence bands of selected semiconducting minerals. Am. Mineral. 85 (3-4), 543-556.

Zotov, A.V., Shikina, N.D., Akinfiev, N.N., 2003. Thermodynamic properties of the $\mathrm{Sb}(\mathrm{III})$ hydroxide complex $\mathrm{Sb}(\mathrm{OH})_{3(\mathrm{aq})}$ at hydrothermal conditions. Geochim. Cosmochim. Acta 67 (10), 1821-1836. 